\title{
DOI:10.14526/2070-4798-2020-15-2-125-129
}

\section{Russian Lapta: from history to reality}

\author{
Irina T. Sharygina*, Dmitriy A. Zubkov, Elena N. Balandina \\ Chaykovskiy State Institute of Physical Culture, Chaykovskiy, Russia \\ ORCID oooo-0oo1-7263-7842, irinasarigina@mail.ru* \\ ORCID oooo-ooo1-9533-0o34, dmitrisubkov@mail.ru \\ ORCID oooo-ooo1-6653-1179, lena balandina 96@mail.ru
}

\begin{abstract}
Understanding changes that happen nowadays in "Russian lapta" is closely connected with the process of its historical roots analysis and its development retrospective analysis. Materials. The results of retrospective analysis of "Russian lapta" formation and development as a kind of sport. Research methods. Information sources analysis and summarizing, documents analysis and summarizing. Results. The article presents the results of retrospective analysis of "Russian lapta" formation and development as a kind of sport. We defined the problems of its further development, presented the recommendations concerning their solution. Conclusion. The received results prove that "Russian lapta" became an independent kind of sport, however, most existing nowadays problems are conditioned by the fact that organizational and juridical aspects of its formation are not finished yet.
\end{abstract}

Keywords: lapta, national game, physical qualities development, available kind of sport.

For citation: Irina T. Sharygina*, Dmitriy A. Zubkov, Elena N. Balandina. Russian Lapta: from history to reality. Russian Journal of Physical Education and Sport. 2020; 15(2): 100-103. DOI:10.14526/2070-47982020-15-2-125-129

\section{INTRODUCTION}

Lapta has ancient history and great geography: this game originated from ancient times and included a lot of national colours [1].

Russian Lapta, American baseball, English cricket, Mexican pelota, Rumanian oyna - all these are names of a popular ball and bat game $[4,8,9,10,11]$.

Nowadays native research workers started to use Russian lapta as the source of traditional for our nationality values, means of the oncoming generation physical upbringing, physical upbringing as the instrument for necessary in life communicative competencies formation and as the platform for tactical and strategic competence formation $[1,3,5,6,7]$.

In 1994 Russian lapta was included into Common All-Russian sports classification and it became an important event on the way to its formation as a national kind of sport, but it didn't solve all problems, which condition the success of its further development.

The aim of the research work is to organize retrospective analysis of lapta formation and development in Russia.

\section{MATERIALS AND METHODS}

Materials of the research were educational, scientific literature, publications in mass media.

Research Methods: Information sources analysis and summarizing, documents analysis

\section{RESULTS AND DISCUSSION}

Researchers of Russian lapta, taking into account Ancient Rus chronicles, came to the conclusion that its history includes more than thousand years [6].

Kostarev A.Yu. in his work, dedicated to the sources of Russian lapta, underlines wide geographical spread of this game on the territory of Russia. It was reflected in the specificity of its names among different nationalities and nations: "matki na vykup", "sgovorka", "na matki”, "tycha”, "shibka”, "bitki”, "khlopta”, "igra v beglye", "v shara”, "uralskiy myach", "koshamaran" and etc.; in forms and sizes of bats for game: there were bats like a big spoon, flat bats, round bats of different diameter (big and small); in the ways of strikes: using one hand or running and in some regions with a turn [2].

During archaeological works equipment for Russian lapta was found (date: XIV century): wooden bats and felt balls [5]. 
With the decree of Peter I Russian lapta was introduced into the content of Preobrazhenskiy and Semenovskiy regiments military training for coordinated tactical actions in defense and attack mastering [4].

In the Russian Empire lapta was the means of active free time of population and the means of physical upbringing of children, teen-agers, young men and girls [2].

On the initiative of N.I. Podvoyskiy for necessary qualities development: courage, sense of community, sharp-sightedness and dexterity, quickness of reaction - lapta was introduced into practice of Red Army men physical upbringing. Being the chairman of High council of physical culture he underlined: “... in Russian lapta there are the sources of high senses - patriotism, faithfulness, combatant endurance ..." [2].

The first official rules of Russian lapta were adopted by High council of Physical Culture in terms of All-Russian Central Executive Committee of Russian Soviet Federative Socialist Republic and published in 1926 [6].

Popularity of lapta among population of the USSR was explained by minimal set of necessary equipment (wooden bat, ball), free demands claimed on the playground (it is possible to play on any playground) and on sports suit and by collective character of this game [2].

The first official Russian lapta competitions were held only in September 1957 in Krasnodar region. In 1958 Lapta was included into the program of All-Russian sports festival of rural athletes and in 1958 the first championship of Russian Soviet Federative Socialist Republic was organized. In 1959 the game was included into the program of the II Summer Sports Festival of RSFSR nationalities [2].

This period is considered the period of Russian lapta development and formation as a national kind of sport: thousands of teams were created in the towns and villages of the USSR.

Since 1960 women teams start to take part in the competitions [6].

In spite of the fact that in 1960 Sports societies and organizations Union of RSFSR reconsidered and adopted new rules of Russian lapta competitions interest in the game started to decrease other kinds of sport: hockey, volleyball, basketball, sports orientation, athletics, figure skating and etc.

A new stage of Russian lapta development started in 1987 with the USSR State Committee of Sport decree "About baseball, softball and Russian lapta development" [6].

Since 1990 official Russian lapta championships of Russia were held again and since 1994 it was included into Common All-Russian sports classification [2].

In 1995 the rules of competitions were transformed and adopted again.

In 1997 general Russian social physical culture-sports organization "Russian lapta federation of Russia" was officially registered in the Russian Federation [2, 6].

In 2003 for the first time final sports lapta competitions were held for the Russian Cup among men and women. As a results, the winners among male teams became the team of Voronezh region and among female teams - the team of the Republic of Bashkortostan.

In 2007 the first Russian lapta International tournament was held. Teams from the Russian Federation and Latvia took part in the tournament.

In 2011 the first specialized lapta stadium in Belgorod was opened [6].

Nowadays in the Russian Federation, according to statistical reports presented by Russian lapta Federation of Russia, 127191 people go in for this game (from them 52023 women) [6].

Sports reserve training in this kind of sport is realized by 82 departments of sports schools in 70 subjects of the Russian Federation. 137 coaches and teachers realize their training activity at these schools. The Federation trained and accredited 260 referees. Sports categories were given to 1249 athletes: 2 masters of sport, 49 candidate master of sports, 90 people, who have the first category, 1108 people have other categories [6].

The greatest Russian lapta competitions include the championships of the first and the second league among men, Russia championship among women. For schoolchildren from villages "Gold bat", "Gold cornfield" tournaments are held. In most subjects of the Russian Federation physical 
culture and sport management bodies organize events directed toward Russian lapta development: championships among educational establishments of secondary and higher education, among veterans (the most important among them is "Black Sea Cup") [5].

It is good news that the idea of giving Russian lapta the status of the national kind of sport is supported by the officials.

At the same time key problems should be underlined. The representatives of Russian lapta Federation faced the following problems:

- "aging" and general lack of the coaches - it is necessary to provide young coaches training and involvement into this kind of sport. For this purpose sports games departments of sports higher educational establishments should organize lessons directed toward sports and pedagogical development of bachelors in this kind of sport;

"information and communicative vacuum" it is necessary to provide communication activation between the organizations, connected with Russian lapta popularization, provide this kind of sport development among population in general;

"lack of game and competitive experience"it is necessary to increase the amount of official competitions, including owing to age categories of participants broadening, involving "amateur" teams;

"lack of young people involvement into systematic Russian lapta lessons"- it is necessary to organize sports playgrounds near houses, ministadiums and support athletes-amateurs.

Most of these problems are in the sphere of business and authority responsibility and demand efforts combination of all interested sides in Russian lapts popularization as a national kind of sport.

\section{CONCLUSION}

The held analysis of lapta formation and development in Russia proves its ancient history, popularity of this game in the past, present and in the future. Russian lapta is a team kind of sport, it doesn't demand considerable investment into equipment. Nowadays Russian lapta goes through the period of renewal. It is characterized by the necessity to combine the efforts of all interested sides in this game development as a national kind of sport.

\section{REFERENCES}

1. Vorobeva N.A., Nikolskaya T.V. Lapta as one of the means of educational process effectiveness improvement at a higher educational establishment. Uchenye zapiski universiteta imeni P.F. Lesgafta. 2020; 1(179): 59-63 [In Russ.].

2. Kostarev A.Yu., Ismagilova R.R., Iksanova K.V. History oflapta development in Russia. Innovacionnye podhody $v$ rekreatsii, turizme I fizicheskoj kul'ture: materialy mezhdunarodnoj nauchno-prakticheskoj konferencii [Innovative approaches in recreation, tourism and physical culture: materials of the International scientificpractical conference]. 2018: 144-149 [In Russ.].

3. Mashoshina I.V. National game lapta as the means of recreational physical upbringing of schoolchildren. Kul'tura fizicheskaya I zdorov'e. 2010; 2 (27):12-15 [In Russ.].

4. Plokhikh N.V. Bringing up the culture of health in the traditions of Russian national game. Sistema cennostej souremennogo obchestva. 2013; 30: 117-123 [In Russ.].

5. Shevko E. V. Russian lapta - historical heritage of native physical culture. Teoretichekie I prakticheskie problem fizicheskoj kul'tury I sporta: materialy Vserossijskoj nauchnoprakticheskoj konferencii $s$ mezhdunarodnym uchastiem [Theoretical and practical problems of physical culture and sport: materials of All-Russian scientific-practical conference with the International participation]. 2016: 78-83 [In Russ.].

6. Official site of general Russian social physical culture-sports organization "Russian lapta Federation in Russia”. URL: https://ruslapta.ru

7. Beaton A.A., Funk D.C., Alexandris K. Operationalising a theory of participation in physical active leisure. Journal of Leisure Research. 2009; 41: 177-203.

8. Dawson P., Downward P. The relationship between participation in sport and sport volunteering: An economic analysis. International Journal of Sport Finance. 2013; 8: 75-92.

9. Eberth B., Smith M.D. Modelling the participation decision and duration of sporting 
activity in Scotland. Economic Modelling. 2010; 27: The development of the ancestors traditions for the 822-834. DOI: 10.1016/j.econmod.2009.10.003 Yakut sports glory. Pedagogiko-psihologicheskie

10. Fridberg T. Sport and exercise I medico-biologicheskie problemy fizicheskoj in Denmark, Scandinavian and Europe. kul'tury I sporta = The Russian Journal of Physical Sport in Society. 2010; 13: 583-592. DOI: Education and Sport. 2018; 13(2): 143-148. DOI: 10.1080/17430431003616225 10.14526/02_2018_319 [In Russ., In Engl.].

11. Kim-Kimen A.N., Kuznetsova Z.M.

\section{Submitted: 18.o6.2020}

\section{Author's information:}

Irina T. Sharygina - Senior Lecturer, Chaikovkiy State Institute of Physical Culture, 617764, Russia, Chaikovskiy, Lenin str., House 67, e-mail: irinasarigina@mail.ru

Dmitriy A. Zubkov - Candidate of Pedagogics, Associate Professor, Chaikovkiy State Institute of Physical Culture, 617764, Russia, Chaikovskiy, Lenin str., House 67, e-mail: dmitrisubkov@mail.ru Elena N. Balandina - Magister, Chaikovkiy State Institute of Physical Culture, 617764, Russia, Chaikouskiy, Lenin str., House 67, e-mail: lena balandina 96@mail.ru 